\title{
EFFECT OF OXIDANT RELATIVE FLOW RATE ON OBTAINING RAW MATERIAL FOR PULVERIZED COAL PRODUCTION FROM HIGH-SULFURIC LOW GRADE COAL
}

\author{
Mariia Shved $^{1}$, Serhiy Pyshyev ${ }^{1, *}$, Yuriy Prysiazhnyi ${ }^{1}$
}

https://doi.org/10.23939/chcht11.02.236

\begin{abstract}
The effect of oxidant relative flow rate on the sulfur removal degree and conversion level of coal organic matter has been determined. Sulfur content, as well as ash content and volatiles yield depend on the mentioned values. The optimal oxidant relative flow rate to realize the oxidative desulfurization process has been found with the aim of obtaining raw material for pulverized coal production.
\end{abstract}

Keywords: oxidant flow rate ratio, oxidative desulfurization, coal organic matter, pulverized coal.

\section{Introduction}

For the production of cast iron the world and Ukrainian metallurgical enterprises use expensive fuel and energy resources (coke and gas) which, in turn, increase the price of finished steel [1]. The partial solving of this problem is pulverized coal injection (PCI) technology, allowing the considerable decrease of natural gas and coke flow rate and reduction of steel production price.

Taking into account the world practice of PCI application [3-4], there are strict requirements for the raw material used in PCI (Table 1), sulfur content in particular. This chemical element is detrimental for blust-furnace production, thus it is desirable the quantity of sulfur in coal would be minimum and does not exceed the quantity of sulfur in coke used for blust-furnace smelting.

The reserves of Ukrainian coal is sufficiently great (approximately 33,873 $\mathrm{mln}$. tons; $3.8 \%$ of world reserves) [6]. However, the source of raw materials which may be used for PCI technology is limited. The reason is a restricted quantity of coal with sulfur content to $1 \%$ (100,000 tons) [7].

\footnotetext{
${ }^{1}$ LvivPolytecnic National University,

12, S. Bandery St., 79013 Lviv, Ukraine

*mari4ka.ved@ukr.net

C) Shved M., Pyshyev S., Prysiazhnyi Yu., 2017
}

To extend the sources of raw materials for PCI technology it is proposed [8] to use an oxidative desulfurization of coal, i.e. selective oxidation of pyrite sulfur, which is the main sulfur in coal, by an oxidant (air or air-steam mixture - ASM) to the sulfur(IV) oxide. The effect of hydrodynamic parameters and process temperature on its main characteristics was described in $[9,10]$. But other parameters may also affect the desulfurization process, ASM : raw material ratio, in particular. The aim of this work is to study the above-mentioned effect.

\section{Experimental}

\subsection{Initial Material}

Low-rank coal from "Belorechenskaya" mine (Donetsk coal basin, Ukraine) was used for the experiments. It was grinded and fraction of $0.1-0.25 \mathrm{~mm}$ was chosen on the basis of previous investigations [9]. The reason for such choice is that just at mentioned coal size the oxidative desulfurization process aimed to produce the raw material for $\mathrm{PCI}$ is the most effective.

The investigated coal is high-sulfuric coal; pyrite sulfur is $51 \%$ of the total sulfur content in it.

\subsection{Experimental M ethods}

Oxidative desulfurization was carried out on a laboratory plant, a block diagram of which is shown in Fig. 1. The plant consists of three main parts:

- Block for oxidant preparing and heating;

- Reaction block;

- Block for trapping and separation of volatile products.

The main unit of the plant is an ideal mixing reactor (with a fluidized bed).

The desulfurization gases were analyzed using LHM-72chromatograph with a thermal conductivity detector. Helium was a carrier-gas. 
Quality requirements for coal effective use in PCI technology [5]

\begin{tabular}{|c|c|c|c|c|c|}
\hline Coal type & Size of coal, mm & $\begin{array}{c}\text { Ash } \\
\text { content, } A^{d}, \%\end{array}$ & $\begin{array}{c}\text { Moisture } \\
\text { content, } W_{t}^{r}, \%\end{array}$ & $\begin{array}{c}\text { Content of total sulfur, } \\
\qquad S_{t}^{d}, \%\end{array}$ & $\begin{array}{c}\text { Volatiles yield, } \\
\quad V^{d a f}, \%\end{array}$ \\
\hline Candle & $0-50$ & $\leq 8.0$ & $\leq 10.0$ & $\leq 1.0$ & $\leq 38.0$ \\
\hline Candle-Gas & $0-50$ & $\leq 8.0$ & $\leq 10.0$ & $\leq 1.0$ & $\leq 38.0$ \\
\hline Gas & $0-50$ & $\leq 8.0$ & $\leq 10.0$ & $\leq 1.0$ & $\leq 38.0$ \\
\hline \multicolumn{6}{|c|}{ Raw material to produce pulverized coal No. 2} \\
\hline Candle & $0-50$ & $\leq 10.0$ & $\leq 11.0$ & $\leq 1.2$ & $\leq 38.0$ \\
\hline Candle-Gas & $0-50$ & $\leq 10.0$ & $\leq 11.0$ & $\leq 1.2$ & $\leq 38.0$ \\
\hline Gas & $0-50$ & $\leq 10.0$ & $\leq 11.0$ & $\leq 1.2$ & $\leq 38.0$ \\
\hline \multicolumn{6}{|c|}{ Raw material to produce pulverized coal No.3 } \\
\hline Candle & $0-70$ & $\leq 10.0$ & $\leq 12.0$ & $\leq 1.5$ & $\leq 38.0$ \\
\hline Candle-Gas & $0-70$ & $\leq 10.0$ & $\leq 12.0$ & $\leq 1.5$ & $\leq 38.0$ \\
\hline Gas & $0-70$ & $\leq 10.0$ & $\leq 12.0$ & $\leq 1.5$ & $\leq 38.0$ \\
\hline \multicolumn{6}{|c|}{ Raw material to produce pulverized coal No.4 } \\
\hline Candle & $0-100$ & $\leq 10.0$ & $\leq 12.0$ & $\leq 1.5$ & $\leq 40.0$ \\
\hline Candle-Gas & $0-100$ & $\leq 10.0$ & $\leq 12.0$ & $\leq 1.5$ & $\leq 40.0$ \\
\hline Gas & $0-100$ & $\leq 10.0$ & $\leq 12.0$ & $\leq 1.5$ & $\leq 40.0$ \\
\hline
\end{tabular}

Table 2

\section{Characteristics of the initial material}

\begin{tabular}{|c|c|c|c|c|c|c|c|c|c|}
\hline \multirow{2}{*}{$\begin{array}{l}\text { Moisture } \\
\text { content, } \\
W^{a}, \text { wt } \%\end{array}$} & \multirow{2}{*}{$\begin{array}{l}\text { Ash content, } \\
A^{d}, \text { wt } \%\end{array}$} & \multirow{2}{*}{$\begin{array}{c}\text { Volatiles } \\
\text { yield, } V^{\text {daf }} \text {, } \\
\text { wt } \%\end{array}$} & \multicolumn{4}{|c|}{$\begin{array}{l}\text { Sulfur content relative to the dry mass, } \\
\text { wt } \%\end{array}$} & \multicolumn{3}{|c|}{$\begin{array}{l}\text { Relative content of sulfur different } \\
\text { types, } \%\end{array}$} \\
\hline & & & $\begin{array}{l}\text { total } \\
\left(S_{t}^{d}\right)\end{array}$ & $\begin{array}{l}\text { pyrite } \\
\left(S_{p}^{d}\right)\end{array}$ & $\begin{array}{c}\text { organic } \\
\left(S_{o}^{d}\right)\end{array}$ & $\begin{array}{l}\text { sulfate } \\
\left(S_{S O_{4}}^{d}\right)\end{array}$ & $S_{p}^{d} / S_{t}^{d}$ & $S_{o}^{d} / S_{t}^{d}$ & $S_{S O_{4}}^{d} / S_{t}^{d}$ \\
\hline 3.91 & 8.15 & 38.08 & 3.29 & 1.67 & 1.25 & 0.37 & 50.76 & 37.99 & 11.25 \\
\hline
\end{tabular}

\begin{tabular}{|c|c|c|c|c|c|}
\hline Water & $\begin{array}{l}\text { Block of air-steam } \\
\text { mixture preparing } \\
\text { and heating }\end{array}$ & $\frac{\text { Coal }}{\text { ASM }}$ & $\begin{array}{c}\text { Oxidative } \\
\text { desulphurisation in } \\
\text { fluidized bed }\end{array}$ & $\sqrt{\begin{array}{c}\text { Gaseous and } \\
\text { vaporous } \\
\text { products }\end{array}} \rightarrow$ & $\begin{array}{l}\text { Recovery and separation of } \\
\text { gaseous and vaporous } \\
\text { products }\end{array}$ \\
\hline & Analysis & urized c & Analysis $\sqrt{\text { Des }}$ & phurization gase & Analysis \\
\hline
\end{tabular}

Fig. 1. Block diagram of the laboratory plant for coal oxidative desulfurization

\subsection{M ethods of Data Processing}

To characterize ASM : raw material ratio we used the term "oxidant flow rate ratio" (OFR). OFR was calculated as the ratio between a volumetric flow of ASM $\left(\mathrm{m}^{3} / \mathrm{h}\right)$ and coal mass $(\mathrm{kg})$.

Based on the weight of the initial coal, yields of COM decomposition resin and desulfurized coal, the sulfur content in the initial and desulfurized coal, volume and composition of desulfurization gases we calculated a number of indices characterizing the process efficiency.

1. The degree of total sulfur conversion (DTSC), \%:

$$
D T S C=\frac{S_{t_{0}}^{a} \cdot 100-S_{t}^{a} \cdot x_{d . c . y}}{S_{t_{0}}^{a}},
$$

where $S_{t_{0}}^{a}$ - the content of total sulfur in the initial coal relative to the analytical sample, wt $\% ; S_{t}^{a}$-the content of total sulfur in the desulfurized coal relative to the analytical sample, wt $\% ; x_{d . c . y}-$ the desulfurizated coal yield, wt $\%$.

2. The degree of pyrite sulfur removal (DPSR) \%:

$$
\operatorname{DPSR}=\frac{S_{p_{0}}^{d}-S_{p}^{d}}{S_{p_{0}}^{d}} \cdot 100
$$

where $S_{p_{0}}^{d}$ - the content of pyritic sulfur in the initial coal relative to the dry sample, wt $\% ; S_{p}^{d}-$ the content of pyritic sulfur in the desulfurized coal relative to the dry sample, wt $\%$. 
3. The degree of coal organic matter conversion (DCOM), \%:

$$
\begin{gathered}
D C O M=\frac{V_{D G}}{22,4 \cdot m_{i c .}} \cdot\left(x_{\mathrm{CH}_{4}}^{\prime} \cdot M_{\mathrm{CH}_{4}}+x_{\mathrm{C}_{2}-\mathrm{C}_{3}}^{\prime} \cdot M_{\mathrm{C}_{2}-\mathrm{C}_{3}}+x_{\mathrm{CO}_{2}}^{\prime} \cdot\right. \\
\left.\cdot M_{\mathrm{C}}+x_{\mathrm{co}}^{\prime} \cdot M_{\mathrm{C}}\right)+x_{\mathrm{rs} .}^{\prime}
\end{gathered}
$$

where $x_{\mathrm{CH}_{4}}^{\prime}, x_{\mathrm{C}_{2}-\mathrm{C}_{3}}^{\prime}$ etc. - concentrations of corresponding components in the desulfurization gases, vol \%; $M_{\mathrm{CH}_{4}}$, $M_{C_{2}-C_{3}}, M_{\mathrm{C}}$ - molecular masses of methane, $\mathrm{C}_{2}-\mathrm{C}_{3}$ hydrocarbonsandcarbon, respectively; $V_{D G}$ - volume of desulfurization gases, $\mathrm{m}^{3} ; m_{i c}$ - weight of the initial coal (quantity of coal loaded into the reactor), $\mathrm{kg} ; x_{\mathrm{rs}}^{\prime}-$ resin, wt $\%$.

4. Efficiency factor of COM conversion $\left(K_{e f}\right)$ :

$$
K_{e f}=\frac{\frac{V_{D G}}{22,4 \cdot m_{i c .}} \cdot\left(x_{C_{H_{4}}^{\prime}}^{\prime} \cdot M_{C_{H_{4}}}+x_{C_{2}-C_{3}}^{\prime} \cdot M_{C_{2}-C_{3}}+x_{\mathrm{co}}^{\prime} \cdot M_{\mathrm{C}}\right)+x_{\mathrm{rs} .}^{\prime}}{\frac{V_{D G}}{22,4 \cdot m_{i c}} \cdot x_{\mathrm{CO}_{2}}^{\prime} \cdot M_{\mathrm{C}}}
$$

5. The degree of ash increase (DAI), \%:

$$
D A I=\frac{A^{d}-A_{0}^{d}}{A_{0}^{d}} \cdot 100,
$$

where $A^{d}$ - ash content of desulfurized coal relative to the dry mass, wt $\% ; A_{0}^{d}-$ ash content of the initial coal relative to the dry mass, wt $\%$

6. Change of volatiles yield (CVY), \%:

$$
C V Y=\frac{V_{0}^{\text {daf }}-V^{\text {daf }}}{V_{0}^{\text {daf }}} \cdot 100,
$$

where $V_{0}^{\text {daf }}$ - yield of volatiles of the initial coal relative to the dry ash-free sample, wt $\%$

The first index (DTSC) describes the quantity of sulfur converted into gaseous sulfur-containing products. This sulfur will not get into atmosphere while using desulfurized coal, i.e. this parameter characterizes the ecological efficiency of oxidative desulfurization.

The second index (DPSR) depends on the sulfur end content in the resulting coal; i.e. it is the ratio between the rates of desired (pyritic sulfur conversion) and undesirable (COM conversion) reactions.

To characterize the depth of COM conversion we calculated the third index (DCOM), which describes the relative quantity of coal spent for the formation of resin and desulfurization gases.
$K_{e f}$ determines the direction of COM conversion, i.e. the ratio between quantity of COM, from which combustible products are formed, and quantity which is burnt (spent for $\mathrm{CO}_{2}$ formation).

The fifth and sixth indices characterize the effect of oxidative desulfurization parameters (in this case oxidant linear velocity and coal particles size) on ash content and volatiles yield of desulfurized coal.

\section{Results and Discussion}

It should be noted that during oxidative desulfurization the ash content increases and volatiles yield (depending on degree of coalification and process conditions) decreases or slightly increases due to COM conversion. Taking into account data from Table 1 we assert that requirements for oxidative desulfurization with the aim of obtaining raw material for PCI differ from those for coal desulfurization described in [11, 12]. If we obtain the raw material for PCI it is necessary to minimize the increase in ash content and volatiles yield (it is desirable volatiles yield would decrease). At the same time the sulfur content in desulfurized coal should not exceed $1.2-1.5 \mathrm{wt} \%$.

The process conditions under which the effect of oxidant : raw material ratio on the oxidative desulfurization is studied are presented in Table 3. We chose them based on data from [9-12]. The investigation results are represented in Tables 4-6 and Figs. 2-8.

One can see from Fig. 2 that increase in OFR within $2.99-12.83 \mathrm{~m}^{3} / \mathrm{h}$ decreases the yield of desulfurized coal by $7.5 \mathrm{wt} \%$. The reason is the increase in intensity of gasification, thermal decomposition and burning of the organic matter. The increase in RFO also increases the quantity of thermal decomposition liquid products formed during the process and evaporated in the oxidant flow. Thus, the increase in OFR increases the yield of COM decomposition resin by $4.4 \mathrm{wt} \%$ (Fig. 3) and degree of COM conversion (Fig. 5). The fuzzy dependence of solid products total yield (coal and decomposition resin) is observed (Fig. 4). The maximum yield of oxidative desulfurization solid products is achieved at OFR equal to $4.8 \mathrm{~m}^{3} / \mathrm{h} \cdot \mathrm{kg}$, i.e. at the mentioned value the COM burning and its thermal decomposition are optimal for this process.

\section{Oxidative desulfurization conditions}

\begin{tabular}{|l|c|}
\hline \multicolumn{1}{|c|}{ Parameter } & Values \\
\hline Time, min & 15 \\
\hline Temperature, $\mathrm{K}$ & 698 \\
\hline Oxidant linear velocity, $\mathrm{m} / \mathrm{s}$ & 0.044 \\
\hline Oxidant compositon, vol\%: & 14.70 \\
$-\mathrm{O}_{2}$ & 30 \\
- steam & \\
\hline
\end{tabular}




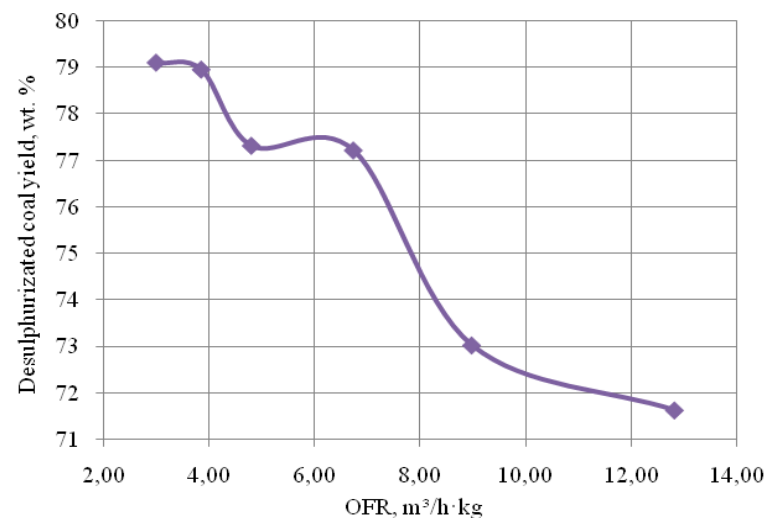

Fig. 2. Desulfurized coal yield vs. OFR

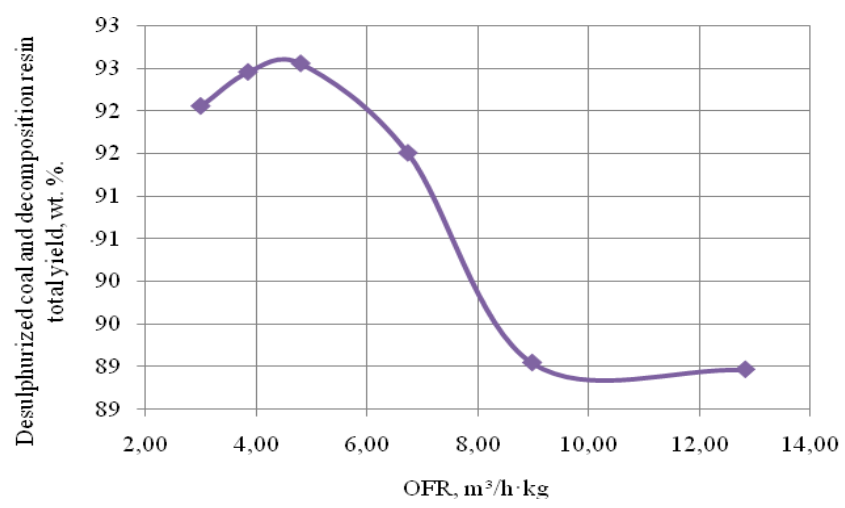

Fig. 4. Solid products yield vs. OFR

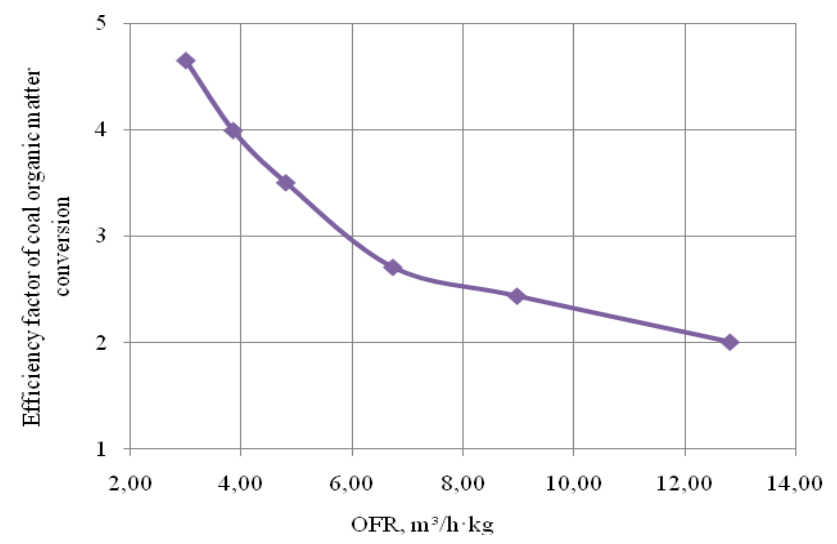

Fig. 6. Efficiency factor of COM conversion $\left(K_{e f}\right) v s$. OFR

One can see from Fig. 6 that the increase in OFR decreases the efficiency factor by almost three units; it means stimulation of COM burning and increase in $\mathrm{CO}_{2}$ quantity in desulfurization gases (Table 4).

Almost all sulfur (pyrite sulfur first of all) which reacts with the oxidant (ASM) converts into sulfur oxide. It is confirmed by negligible quantity of $\mathrm{H}_{2} \mathrm{~S}$. The content

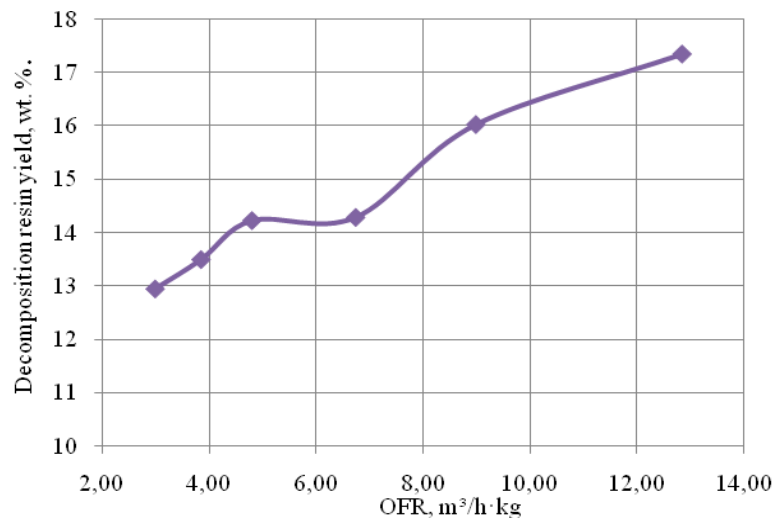

Fig. 3. Decomposition resin yield $v s$. OFR

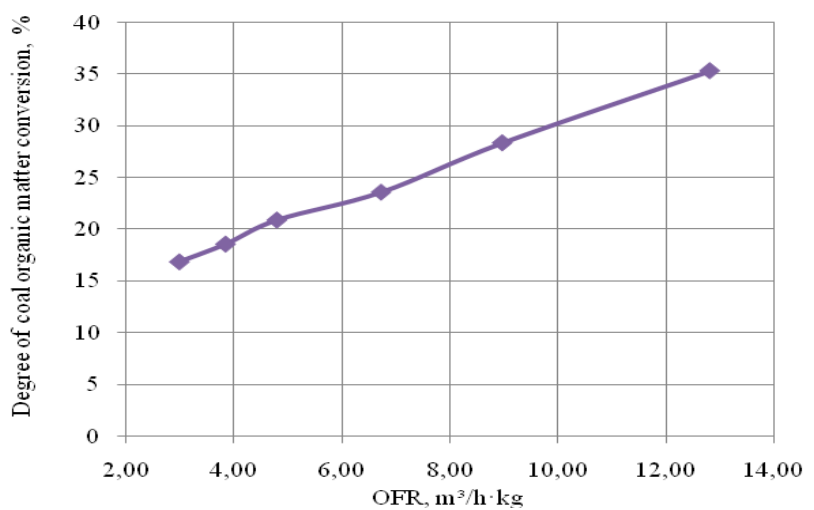

Fig. 5. Degree of COM conversion (DCOM) vs. OFR

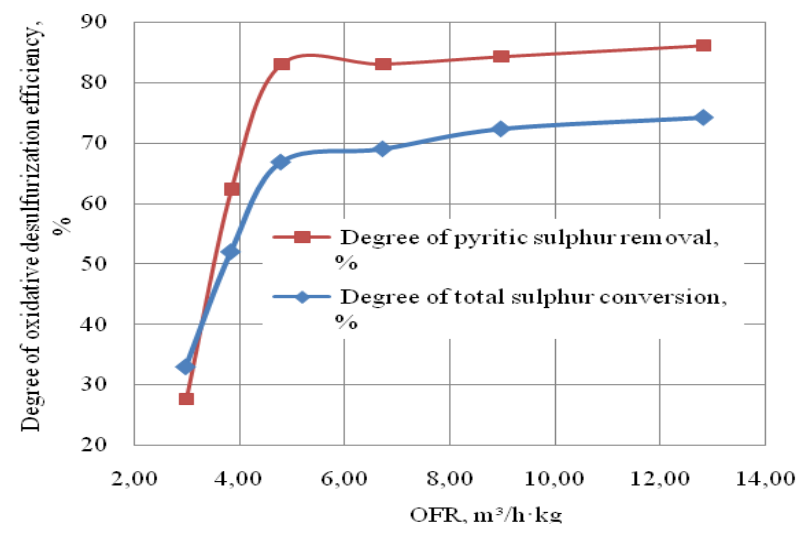

Fig. 7. Degree of total sulfur conversion and degree of pyrite sulfur removal $v s$. OFR

of sulfur(IV) oxide increases with the increase in OFR to $4.8 \mathrm{~m}^{3} / \mathrm{h} \cdot \mathrm{kg}$. Further increase in OFR decreases $\mathrm{SO}_{2}$ concentration in desulfurization gases. We explain this by the fact that quantity of removed sulfur at OFR $>4.8 \mathrm{~m}^{3} / \mathrm{h} \cdot \mathrm{kg}$ is practically constant (see Table 6); at the same time the volume of desulfurization gases increases considerably. 
So, the increase in OFR provides:

i) the increase in ash content and, consequently, the increase in DAI;

ii) the decrease in volatiles yield and, consequently, the increase in CVY.

The first item is related to the decrease of COM during the process, the second - to the decrease of thermally unstable compounds in desulfurized coal.

The increase in OFR decreases the content of pyrite and total sulfur in desulfurized coal (Table 6) and increases degree of total sulfur conversion, as well as degree of pyrite sulfur removal (Fig. 7). The highest rate of pyrite sulfur oxidation is achieved at $\mathrm{ORF}=4.8 \mathrm{~m}^{3} / \mathrm{h} \cdot \mathrm{kg}$. Further increase in ORF actually does not affect degrees of sulfur conversion and removal (Fig. 7).

Fig. 8 represents ORF regions, where requirements for desulfurized coal relative to sulfur content, ash content and volatiles yield are satisfied from the standpoint of coal using for PCI technology. ORF optimum values were found to be within $4.34-4.53 \mathrm{~m}^{3} / \mathrm{h} \cdot \mathrm{kg}$ under the process conditions given in Table 3 .

\section{Conclusions}

The maximum yield of oxidative desulfurization solid products (coal and decomposition resin) is achieved at ORF equal to $4.8 \mathrm{~m}^{3} / \mathrm{h} \cdot \mathrm{kg}$. The increase in ORF increases the degree of COM conversion, ash content and decreases volatiles yield. The degrees of sulfur conversion and removal increase with the increase of ORF value to $4.8 \mathrm{~m}^{3} / \mathrm{h} \cdot \mathrm{kg}$. Further increase in ORF actually does not influence these values. Maximum concentration of sulfur dioxide in desulfurization gases is achieved at the same ORF value.

As a result of low grade coal oxidative desulfurization, at ORF $4.34-4.53 \mathrm{~m}^{3} / \mathrm{h} \cdot \mathrm{kg}$, it is possible to obtain raw materials for the production of pulverized coal No. 3-4. The obtained coal meets all requirements relative sulfur content, ash content and volatiles yield. At ORF above $9.62 \mathrm{~m}^{3} / \mathrm{h} \cdot \mathrm{kg}$ the obtained product meets the requirements for the production of pulverized coal No. 2 relative to sulfur content and volatile yield. Ash content does not meet the requirements.

Table 4

Composition of desulfurized gases

\begin{tabular}{|c|c|c|c|c|c|c|c|c|c|}
\hline \multirow{2}{*}{$\begin{array}{c}\text { OFR, } \\
\mathrm{m}^{3} / \mathrm{h} \cdot \mathrm{kg}\end{array}$} & \multicolumn{9}{|c|}{ Content, vol \% } \\
\hline & $\mathrm{CH}_{4}$ & $\mathrm{C}_{2}-\mathrm{C}_{3}$ & $\mathrm{SO}_{2}$ & $\mathrm{H}_{2} \mathrm{~S}$ & $\mathrm{CO}$ & $\mathrm{CO}_{2}$ & $\mathrm{O}_{2}$ & $\mathrm{~N}_{2}$ & $\mathrm{Ar}$ \\
\hline 2.99 & 0.89 & 0.34 & 1.01 & 0.01 & 1.01 & 9.61 & 6.11 & 79.29 & 0.93 \\
\hline 3.85 & 0.83 & 0.47 & 1.39 & 0.09 & 1.14 & 9.88 & 5.93 & 79.22 & 0.92 \\
\hline 4.80 & 0.71 & 0.71 & 1.46 & 0.05 & 1.28 & 9.74 & 5.90 & 78.90 & 0.91 \\
\hline 6.74 & 0.70 & 0.71 & 1.10 & 0.09 & 1.48 & 10.01 & 5.85 & 79.27 & 0.91 \\
\hline 8.98 & 0.69 & 0.67 & 0.87 & 0.07 & 1.86 & 10.07 & 5.54 & 79.64 & 0.93 \\
\hline 12.83 & 0.68 & 0.69 & 0.87 & 0.08 & 2.08 & 10.40 & 5.46 & 79.85 & 0.93 \\
\hline
\end{tabular}

Table 5

Dependence of desulfurized coal properties on OFR

\begin{tabular}{|c|c|c|c|c|c|}
\hline OFR, $\mathrm{m}^{3} / \mathrm{h} \cdot \mathrm{kg}$ & $\begin{array}{c}\text { Moisture content, } \\
W^{a}, \mathrm{wt} \%\end{array}$ & $\begin{array}{c}\text { Ash content, } A^{d}, \mathrm{wt} \\
\%\end{array}$ & $\begin{array}{c}\text { The degree of ash } \\
\text { increase, DAI, } \%\end{array}$ & $\begin{array}{c}\text { Volatiles yield, } V^{d a f}, \\
\text { wt } \%\end{array}$ & $\begin{array}{c}\text { Change of volatiles } \\
\text { yield, CVY, } \%\end{array}$ \\
\hline 2.99 & 1.33 & 9.33 & 14.53 & 39.03 & -2.51 \\
\hline 3.85 & 1.25 & 9.67 & 18.66 & 38.32 & -0.63 \\
\hline 4.80 & 1.17 & 10.13 & 24.28 & 37.66 & 1.10 \\
\hline 6.74 & 1.12 & 10.43 & 27.94 & 34.00 & 10.73 \\
\hline 8.98 & 1.10 & 10.52 & 29.03 & 32.29 & 15.19 \\
\hline 12.83 & 0.98 & 10.61 & 30.23 & 30.82 & 19.06 \\
\hline
\end{tabular}

Table 6

Sulfur content in desulfurized coal

\begin{tabular}{|c|c|c|c|c|}
\hline \multirow{2}{*}{ OFR, $\mathrm{m}^{3} / \mathrm{h} \cdot \mathrm{kg}$} & \multicolumn{4}{|c|}{ Sulfur content, wt \% } \\
\cline { 2 - 5 } & total $\left(S_{t}^{d}\right)$ & pyrite $\left(S_{p}^{d}\right)$ & organic $\left(S_{o}^{d}\right)$ & sulfate $\left(S_{S O_{4}}^{d}\right)$ \\
\hline 2.99 & 2.72 & 1.21 & 0.19 & 0.73 \\
\hline 3.85 & 1.95 & 0.28 & 0.20 & 0.75 \\
\hline 4.80 & 1.36 & 0.28 & 0.21 & 0.79 \\
\hline 6.74 & 1.28 & 0.26 & 0.22 & 0.85 \\
\hline 8.98 & 1.21 & 0.23 & 0.29 & 1.02 \\
\hline 12.83 & 1.15 & 0.63 & 0.30 & 1.21 \\
\hline
\end{tabular}




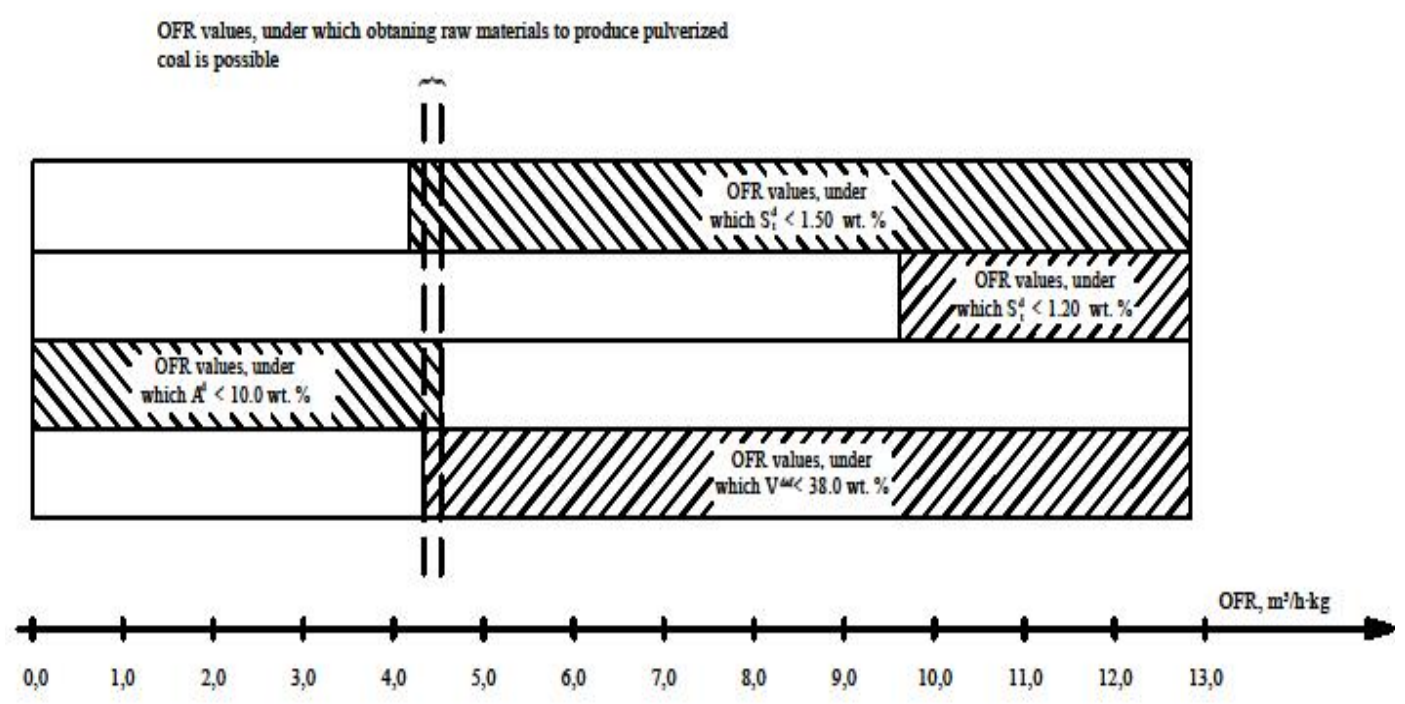

Fig. 8. ORF values, under which the raw material for PCI may be obtained

To determine process parameters under which optimum ratio of sulfur and COM conversion rates is achieved, i.e. to obtain coal with a sulfur content of $1.2 \mathrm{wt} \%$, ash content of $10 \mathrm{wt} \%$ and volatiles yield of $38 \mathrm{wt} \%$ it is necessary to study in future the effect of process time and oxidant composition.

\section{References}

[1] Lohutova T., Poltoratska O.: Innovatsiina Ekonomika, 2015, 1, 18.

[2] Yaroshevskiy S., Emchenko A., Popov V. et al.: Metal i Litie Ukrainy, 2010, 7, 13.

[3] Hutny W., Lee G., Price J.: Progr. Energ. Combust. Sci., 1991, 17, 373. https://doi.org/10.1016/0360-1285(91)90008-B

[4] Diez M., Alvarez R., Barriocanal C.: Int. J. Coal Geology, 2002, 50, 389. https://doi.org/10.1016/S0166-5162(02)00123-4

[5] Standards of Ukraine: TU U 10.1-30962337-006:2009, 2012.

[6] BP Statistical Review of World Energy June 2016. https://www.bp.com/content/dam/bp/pdf/energy-

economics/statistical-review-2016/bp-statistical-review-of-worldenergy-2016-full-report.pdf

[7] Drozdnik I., Starovoit A., Gusak V. et al.: Ugli dlia Koksovania i Pyleugolnogo Topliva. IPP Kontrast, Kharkov 2011.

[8] Pyshyev S., Prysiazhnyi Yu., Shved M.: Uglechim. Zh., 2015, 6, 10. [9] Pyshyev S., Prysiazhnyi Yu., Shved M.: Techn. Audit i Reservy Vyrobnytsva, 2016, 3, 48. https://doi.org/10.15587/2312-8372.2016.70858

[10] Shved M., Prysiazhnyi Yu., Pyshyev S.: Uglechim. Zh., 2017, 1 (in press)

[11] Pyshyev S., Bilushchak H., Gunka V.: Chem. Chem. Technol., 2012, 6, 105.

[12] Pyshyev S., Gunka V., Astakhova O. et al.: Chem. Chem. Technol., 2013, 7, 327.

Received: December 12, 2016 / Revised: February 12, 2017 / Accepted: M arch 03, 2017

\section{ВПЛИВ ВІДНОСНОЇ ВИТРАТИ ОКСИДАНТУ НА ПРОЦЕС ОДЕРЖАННЯ СИРОВИНИ ДЛЯ ВИРОБНИЦТВА ПИЛОВУГІЛЬНОГО ПАЛИВА 3 ВИСОКОСУЛЬФУРИСТОГО НИЗЬКОМЕТАМОРФІЗОВАНОГО ВУГІЛЛЯ}

Анотація. Досліджено вплив відносної витрати оксиданту на ступені вилучення сірки та глибину перетворення органічної маси вугілля, від яких залежсать, відповідно, вміст сірки, з одного боку, та зольність і вихід летких знесірчуваного вугілля, з іншого. Знайдено оптимальні значення відносної витрати оксиданту, за яких рекомендується здійснювати процес оксидачійного знесірчування з метою одержання сировини для виробництва пиловугільного палива.

Ключові слова: кратність витрати оксиданту, оксидачійне знесірчування, органічна маса вугілля, пиловугільне паливо. 